\title{
Epidemiological aspects of suicide among the young in selected European countries
}

\author{
GUIDO F G MOENS, WIM HAENEN, AND HERMAN VAN DE VOORDE \\ From the Division of Community Medicine, School of Public Health, Catholic University Leuven, Vital \\ Decosterstraat 102, B-3000 Leuven, Belgium
}

SUMmARY Trends in reported suicide rates were analysed for the ages 5-24 years in 21 selected European countries in 1970-74 and 1980-84. In children the precision of the rates was found to be low though there appeared to be a trend to increased suicide in boys. In adolescent and young adult males, however, there was a definite increase in suicide over the period studied, and this was much more marked than in females, in whom the rates had declined in eight countries. The Belgian situation was investigated in detail. Increases were most pronounced in 20-24 year-öld males. Around 1981, about half of youth suicides were committed by firearms and medicaments, and these methods showed the largest increases in risk. The estimated under-reporting error diminished with increasing age and over the past ten years. It was larger in females, but did not bias the trends substantially. On the aggregated level, youth suicide was found most strongly associated with indicators of anomie and social isolation. The relevance of these findings in the search for determinants and for preventive strategies is discussed.

Suicidal behaviour among the young has been recognised as a public health problem of increasing importance. $^{1-8}$ In most industrialised countries important increases in the rates of attempted and completed suicide among young people have been reported $^{12}$ and the rise has received special notice and comment in the United States. ${ }^{5-8}$ In this respect, the importance of firearm suicides has been stressed ${ }^{5-9}$ and official recommendations aiming at prevention are now being circulated. ${ }^{7-10}$

The epidemiological study of suicide among the young is faced with many difficulties. Problems with the statistical description and analysis (the generally small numbers of observations), with the validity of the data (under-reporting and definition problems), and with study design (known to hamper inferences in suicide epidemiology) tend to be much more pronounced in the young age groups.

This paper is concerned with the trends in reported suicide rates in the age group 5 to 24 years in 21 selected European countries over the past decade. In addition, the trends in Belgium are analysed in depth for patterns in methods, in the geographical distribution, and for socio-demographic correlates.

For all ages, Belgium ranked second in 1984 among the EEC countries for female suicide mortality with an age-standardised rate of 14.4 per 100000 population, and third for males with $32 \cdot 2$ per $100000 .^{11}$ The crude rate increased by $34 \%$ between 1970 and 1981 and the rise was most obvious after 1975, especially in males. ${ }^{11} 12$ The changes in the age, sex and geographical characteristics and the ecologial determinants have been reported elsewhere. ${ }^{12-14}$

\section{Materials and methods}

The mortality rates for suicide (ICD code, 8 th and 9 th Revision: E950-E959) for 21 European countries were extracted from the yearbooks published by the World Health Organisation (WHO). ${ }^{11}$ Two periods of five years (1970-74 and 1980-84) were averaged to minimise the random fluctuation.

The countries were selected on the basis of the availability of published data for at least three years within the investigated periods. WHO standard age groupings (5-14 and 15-24 years) were used. Rank correlation analysis was applied to analyse the consistency of the geographical patterns.

For Belgium we made use of data published by the Ministry of Public Health ${ }^{15}$ for the period 1955-1984, and the death certificate files of the National Institute of Statistics (NIS, Brussels) from 1968 on. The death certificates were cross-tabulated according to age, sex, method and geographical arrondissement (district). Data were analysed in 5-year and 10-year age groups. 
Some causes of death which might lead to a misclassification of real suicide deaths ${ }^{16}$ were also investigated: so-called "undetermined deaths" (ICD code E980-E989 from 1969 on) and "accidental poisoning" (ICD-code 9th Revision E850-E869).

For the method-specific and for the geographical analysis, average annual rates were computed over periods of five or six years.

Finally, the geographical variation of selected sociodemographic variables across the 43 Belgian arrondissements was correlated ${ }^{14}$ with the variation in the (indirectly age-standardised) suicide rates for the 15- to 24-year-olds in two periods: 1968-72 and 1979-84. In the correlation analysis, each case was weighted ${ }^{14}$ using the reciprocals of the variance of the suicide rate, to take account of the varying precision of the mortality rates. ${ }^{17}$

Details about the selection of the sociodemographic factors, the computation of the rates and the statistical analysis will be reported elsewhere.

\section{Results}

Table 1 displays the average sex-specific suicide rates. Especially in the 5-14 years group, the low precision of the figures for rates and percentage change has to be considered. Rates given by the WHO were only to one decimal place and many of the rates were based on very few observations. Thus one has to take account of large random variation in the rates and the percentages. No obvious trends were apparent in this age group, although in boys there was a tendency for countries to show increases (significant sign-test ${ }^{17}$ ). For the 15-24 year-olds, there was a significant trend to increased rates in males but not in females.

A comparison of the geographical patterns (ranking) between age groups and periods showed strong and positive associations in time and with the mortality for all ages. However, in the 5-14 years group the coefficients tended to be smaller, partly due to the large random error of the rates. Sweden and Czechoslovakia showed decreases for all the considered age and sex groups.

The proportion of youth suicides in the overall burden of suicides in the 21 countries hardly changed between 1970-74 and 1980-84: in boys (5-14 years old) from $0.6 \%$ to $0.5 \%$, in girls from $0.3 \%$ to $0.4 \%$; in male adolescents (15-24 years old) from $9 \cdot 8$ to $10 \cdot 1 \%$ and in females from $7 \cdot 1$ to $6.5 \%$.

For Belgium, we analysed the pattern in more depth. Fig 1 shows the trends for selected age groups from 1955 to 1980 . Five years around each time point were averaged to yield more stable rates. In male adolescents, a sharp rise was seen after 1970 (since

Table 1 Average annual sex-specific suicide rates (per 100000 population) among the young (5-14 and 15-24 years old) in 1970-74 and in 1980-84 in 21 selected European countries

\begin{tabular}{|c|c|c|c|c|c|c|c|c|c|c|c|c|}
\hline \multirow[b]{3}{*}{$\begin{array}{l}\text { European } \\
\text { Countries }\end{array}$} & \multicolumn{6}{|l|}{ Males } & \multicolumn{6}{|l|}{ Females } \\
\hline & \multicolumn{3}{|c|}{ Age 5-14 years } & \multicolumn{3}{|c|}{ Age $15-24$ years } & \multicolumn{3}{|c|}{ Age 5-14 years } & \multicolumn{3}{|c|}{ Age 15-24 years } \\
\hline & $\begin{array}{l}\text { Average } \\
\text { rate } \\
1970-74\end{array}$ & $\begin{array}{l}\text { Average } \\
\text { rate } \\
1980-84\end{array}$ & $\begin{array}{l}\% \\
\text { change } \\
\text { in rate }\end{array}$ & $\begin{array}{l}\text { Average } \\
\text { rate } \\
1970-74\end{array}$ & $\begin{array}{l}\text { Average } \\
\text { rate } \\
1980-84\end{array}$ & $\begin{array}{l}\% \\
\text { change } \\
\text { in rate }\end{array}$ & $\begin{array}{l}\text { Average } \\
\text { rate } \\
1970-74\end{array}$ & $\begin{array}{l}\text { Average } \\
\text { rate } \\
1980-84\end{array}$ & $\begin{array}{l}\% \\
\text { change } \\
\text { in rate }\end{array}$ & $\begin{array}{l}\text { Average } \\
\text { rate } \\
1970-74\end{array}$ & $\begin{array}{l}\text { Average } \\
\text { rate } \\
1980-84\end{array}$ & $\begin{array}{l}\% \\
\text { change } \\
\text { in rate }\end{array}$ \\
\hline Austria & 1.8 & $2 \cdot 5$ & +39 & $27 \cdot 3$ & $38 \cdot 2$ & +40 & $0.3^{*}$ & $0.6^{*}$ & +100 & $6 \cdot 3$ & $8 \cdot 1$ & +29 \\
\hline Belgium (a) & - & $1 \cdot 1^{*}$ & $+(/)$ & $9 \cdot 1$ & $16 \cdot 5$ & +81 & - & $0 \cdot 3^{*}$ & $+(/)$ & $3 \cdot 5$ & $4 \cdot 6$ & +31 \\
\hline Bulgaria & 0.9 & $1 \cdot 2$ & +33 & $9 \cdot 1$ & 10.8 & +19 & $0.5^{*}$ & $0.7^{*}$ & +40 & $4 \cdot 0$ & 5.6 & +40 \\
\hline Czechoslovakia (c) & $2 \cdot 4$ & 0.7 & -71 & $27 \cdot 5$ & 16.4 & -40 & $0.4^{*}$ & $0 \cdot 2^{*}$ & -50 & $8 \cdot 8$ & $4 \cdot 2$ & -52 \\
\hline Denmark & $0.4^{*}$ & $0.6^{*}$ & +50 & $13 \cdot 3$ & $17 \cdot 2$ & +29 & $0 \cdot 2^{*}$ & $0 \cdot 2^{*}$ & 0 & 5.9 & 5.8 & -2 \\
\hline England \& Wales & $0.1 *$ & $0 \cdot 1^{*}$ & 0 & $5 \cdot 8$ & 6.8 & +17 & $0 \cdot 1^{*}$ & $0 \cdot 1^{*}$ & 0 & $2 \cdot 8$ & $2 \cdot 2$ & $-2 i$ \\
\hline Finland & $0.8^{*}$ & $1.0^{*}$ & +25 & $29 \cdot 7$ & $34 \cdot 4$ & +16 & $0.4^{*}$ & $0 \cdot 2^{*}$ & -50 & $8 \cdot 1$ & $6 \cdot 1$ & -24 \\
\hline France & 0.7 & 0.7 & 0 & $10 \cdot 5$ & 15.6 & +49 & $0 \cdot 1$. & $0 \cdot 2^{*}$ & +100 & $4 \cdot 4$ & $5 \cdot 0$ & +14 \\
\hline Germany FR & 1.1 & $1 \cdot 7$ & +55 & $20 \cdot 2$ & $20 \cdot 0$ & -1 & 0.4 & 0.5 & +25 & 6.9 & 5.9 & -14 \\
\hline Greece & $0.01 *$ & $0.5^{*}$ & +500 & 2.5 & 3.7 & +48 & $0 \cdot 1^{*}$ & $0 \cdot 2^{*}$ & +100 & 1.6 & $1 \cdot 7$ & +6 \\
\hline Hungary & 1.6 & $2 \cdot 3$ & +44 & 27.5 & 28.5 & +4 & $0.5^{*}$ & $0.6^{*}$ & +20 & 8.8 & 8.7 & -1 \\
\hline Iceland (b) & - & $1.9 *$ & $+(/)$ & $15 \cdot 7^{*}$ & $23 \cdot 1^{*}$ & +47 & - & - & $(/)$ & $1 \cdot 0^{*}$ & $2 \cdot 8$ & +180 \\
\hline Ireland (c) & - & $0 \cdot 1^{*}$ & $+(/)$ & 3.6 & $10 \cdot 1$ & +178 & - & $0 \cdot 1^{*}$ & $+(/)$ & $0.8^{*}$ & $2 \cdot 6^{*}$ & +225 \\
\hline Luxembourg (b) (d) & $1.0^{*}$ & $1.8^{*}$ & +80 & $7 \cdot 7 *$ & $15 \cdot 4^{*}$ & +100 & $1 \cdot 0^{*}$ & - & -100 & $3 \cdot 0^{*}$ & $5 \cdot 7^{*}$ & +90 \\
\hline Netherlands & 0.5 & $0.5^{*}$ & 0 & $6 \cdot 3$ & 7.0 & +11 & $0 \cdot 2^{*}$ & $0 \cdot 1^{*}$ & -50 & $2 \cdot 7$ & $3 \cdot 8$ & +41 \\
\hline Northern Ireland & $0 \cdot 2^{*}$ & $0 \cdot 1^{*}$ & -50 & $2 \cdot 7^{*}$ & 8.4 & +211 & - & $0 \cdot 2^{*}$ & $+(/)$ & $1 \cdot 3^{*}$ & $2 \cdot 5^{*}$ & +92 \\
\hline Norway & $0.4^{*}$ & $1 \cdot 2 *$ & +200 & $9 \cdot 3$ & $21 \cdot 3$ & +129 & $0.1^{*}$ & $0 \cdot 1^{*}$ & 0 & 3.4 & $4 \cdot 0$ & +18 \\
\hline Portugal (b) & $0.6^{*}$ & $0.7^{*}$ & +17 & $4 \cdot 1$ & 8.0 & +95 & $0.5^{*}$ & $1 \cdot 0^{*}$ & +100 & $2 \cdot 4$ & 4.9 & +104 \\
\hline Scotland & $0 \cdot 2 *$ & $0 \cdot 1 *$ & -50 & $7 \cdot 4$ & 6.9 & -7 & - & $0 \cdot 2^{*}$ & $+(/)$ & $2 \cdot 1$ & 1.9 & -10 \\
\hline Sweden (e) & $0.4^{*}$ & $0 \cdot 2 *$ & -50 & $17 \cdot 6$ & $15 \cdot 5$ & -12 & $0 \cdot 2^{*}$ & - & -100 & $8 \cdot 0$ & 5.7 & -29 \\
\hline Switzerland (e) & $1 \cdot 0^{*}$ & $1 \cdot 4^{*}$ & +40 & $22 \cdot 1$ & $34 \cdot 7$ & +57 & $0 \cdot 3^{*}$ & $0.4^{*}$ & +33 & $6 \cdot 2$ & $9 \cdot 1$ & +47 \\
\hline \multicolumn{2}{|c|}{ All countries combined 0.8} & 0.9 & +13 & $13 \cdot 7$ & $15 \cdot 5$ & +13 & 0.2 & 0.3 & +50 & 4.9 & $4 \cdot 7$ & -4 \\
\hline \multicolumn{2}{|c|}{ Sign-test(two-sided) } & & $\begin{array}{l}p<0.05 \\
(n=18)\end{array}$ & & & $\begin{array}{l}\mathrm{p}<0.01 \\
(\mathrm{n}=21)\end{array}$ & & & $\begin{array}{l}\text { NS } \\
(n=17)\end{array}$ & & & $\begin{array}{l}\text { NS } \\
(n=21)\end{array}$ \\
\hline
\end{tabular}

(a) Three year average in 1980-84; (b) Four year average in 1970-74; (c) Four year average in 1980-84; (d) 1985 instead of 1981; (e) 1969 instead of 1970; (*) Based on less than 30 observations (deaths) over the considered period; (/) Percentage change not computable. 
when the rates have doubled), which was most pronounced in the 20-24 year-olds. In adult men ( 25 years and older) the rise was obvious only after 1975. In females, the increases were much smaller and more gradual. However, after 1970 a sharpening was also seen in the 20-24 year-old age group. In children below 15 years, only boys showed an increase.

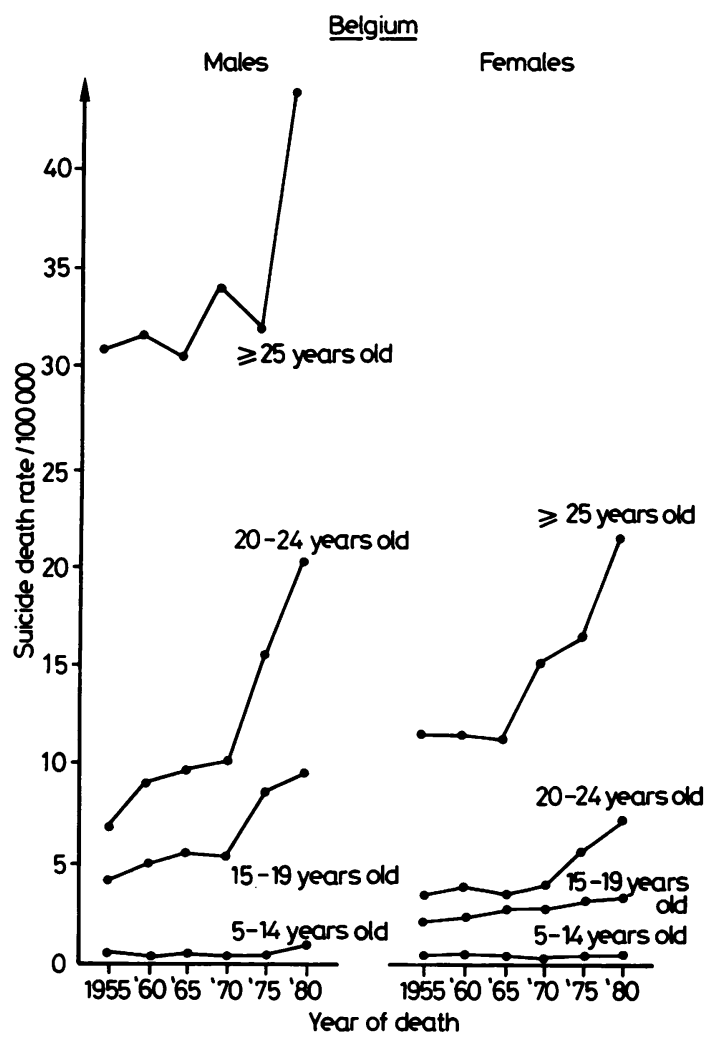

Fig 1 Trends in suicide rates (per 100 000) according to age group between 1955 and 1980 (five-year averages); Belgium

The proportional contribution of young males to the total number of suicides increased between 1950 and 1980 in the $15-19$ year-olds from $1 \cdot 3 \%$ to $2 \cdot 8 \%$, and in 20-24 year-olds from $2.4 \%$ to $5.9 \%$; in females the changes were respectively from $1.6 \%$ to $1.7 \%$ and from $3.0 \%$ to $3.7 \%$.

Table 2 shows the proportional distribution of suicide methods among the 15-24 year-olds in the period 1968-72 and 1979-84. Noteworthy were the increases in the use of firearms and of poisoning with solid and liquid substances in both sexes, the former more pronounced in males, the latter in females. Around 1981 these two methods accounted for nearly half of all young suicide deaths. However, proportional mortality figures could be misleading when assessing trends because they are proportional to the overall suicide mortality, which increased between both periods: in males from 7.84 to 15.36 per 100000 , in females from $3 \cdot 15$ to $4 \cdot 87$.

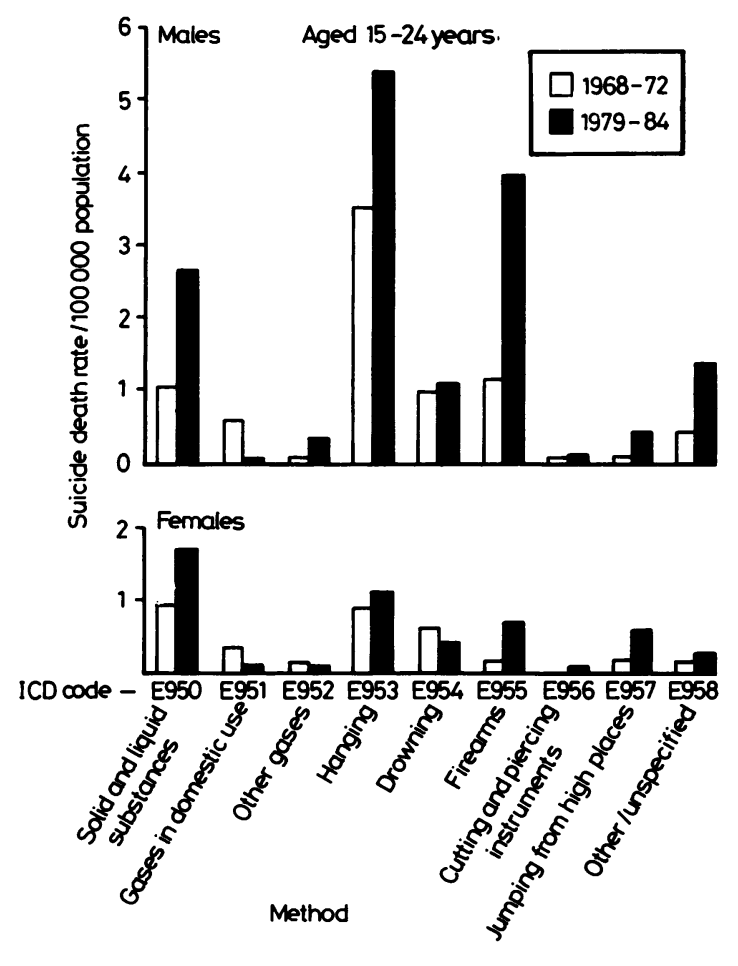

Fig 2 Evolution of the method-specific suicide rates (per 100 000) between 1968-72 and 1979-84 for the age group 15-24 years; Belgium

To take account of real changes in risk, methodspecific rates were computed. These are displayed in fig 2. Apart from the decreased use of domestic gases, the rate for every method increased in males, especially for firearms, self-poisoning and hanging (which decreased proportionally!). In females self-poisoning, firearms, jumping and hanging showed increases, which were however much smaller than in males. A comparison with the trends for all ages combined showed higher proportional and rate increases for firearms and poisoning among the young. The analysis in the age group 5-14 years was hampered by small numbers. In boys, hanging was used in all 
Table 2 Proportional distribution (\%) of methods of suicide in the age group 15-24 years in 1968-72 and 1979-84; Belgium

\begin{tabular}{|c|c|c|c|c|}
\hline \multirow{2}{*}{$\begin{array}{l}\text { Method of suicide } \\
\text { (ICD 8th/9th code) }\end{array}$} & \multicolumn{2}{|l|}{ Males } & \multicolumn{2}{|l|}{ Females } \\
\hline & $1968-72$ & $1979-84$ & $1968-72$ & $1979-84$ \\
\hline Poisoning by solid or liquid substances (E950) & 13.4 & $17 \cdot 2$ & $28 \cdot 3$ & $36 \cdot 1$ \\
\hline Poisoning by domestic gas (E951) & $7 \cdot 2$ & 0.3 & 8.8 & 0.4 \\
\hline Poisoning by other gases (E952) & 0.7 & $2 \cdot 3$ & 1.8 & 0.4 \\
\hline Hanging, strangulation \& suffocation (E953) & $44 \cdot 3$ & $35 \cdot 9$ & $28 \cdot 3$ & $23 \cdot 3$ \\
\hline Drowning (E954) & $12 \cdot 4$ & 6.8 & 18.6 & $7 \cdot 5$ \\
\hline Firearms and explosives (E955) & $14 \cdot 4$ & $25 \cdot 5$ & $5 \cdot 3$ & $14 \cdot 5$ \\
\hline Cutting and piercing instruments (E956) & 0.7 & 0.8 & 0 & $1 \cdot 3$ \\
\hline Jumping from high places (E957) & $1 \cdot 7$ & $2 \cdot 5$ & $2 \cdot 7$ & $11 \cdot 0$ \\
\hline Other and unspecified (E958) & $4 \cdot 8$ & $8 \cdot 7$ & $5 \cdot 3$ & $5 \cdot 3$ \\
\hline Late effects (E959) & 0.3 & 0 & 0.9 & 0 \\
\hline Total & $\begin{array}{l}100 \\
(n=291)\end{array}$ & $\begin{array}{l}100 \\
(n=746)\end{array}$ & $\begin{array}{l}100 \\
(n=112)\end{array}$ & $\begin{array}{l}100 \\
(n=227)\end{array}$ \\
\hline
\end{tabular}

Table 3 Trends in mortality rates for suicide and related categories (per 100000 population) according to age group in 1969-72 and 1979-84; Belgium

Males

\begin{tabular}{|c|c|c|c|c|c|c|c|c|c|c|c|c|}
\hline \multirow[b]{2}{*}{ Age group $b$} & \multicolumn{5}{|c|}{$1969-72^{a}$} & \multicolumn{5}{|l|}{ 1979-84 } & \multirow[b]{2}{*}{$\begin{array}{l}\text { Percentage } \\
\text { change in } \\
\text { suicide } \\
\text { J rate }\end{array}$} & \multirow[b]{2}{*}{$\begin{array}{l}\text { Percentage } \\
\text { change in } \\
\text { estimated } \\
\text { suicide } \\
\text { rate }\end{array}$} \\
\hline & $\begin{array}{l}\text { Suicide } \\
\text { (I) }\end{array}$ & $\begin{array}{l}\text { Undeter- } \\
\text { mined } \\
\text { (2) }\end{array}$ & $\begin{array}{l}\text { Accidental } \\
\text { poisoning } \\
\text { (3) }\end{array}$ & $\begin{array}{l}\text { Estimated } \\
\text { suicide } \\
(4)= \\
(1+2+3)\end{array}$ & $\begin{array}{l}\text { Estimated } \\
\text { under- } \\
\text { reporting } \\
{[(2+3) / 4]} \\
\times 100\end{array}$ & $\begin{array}{l}\text { Suicide } \\
\text { (1) }\end{array}$ & $\begin{array}{l}\text { Undeter- } \\
\text { mined } \\
\text { (2) }\end{array}$ & $\begin{array}{l}\text { Accidental } \\
\text { poisoning } \\
\text { (3) }\end{array}$ & $\begin{array}{l}\text { Estimated } \\
\text { suicide } \\
(4)= \\
(1+2+3)\end{array}$ & $\begin{array}{l}\text { Estimated } \\
\text { under- } \\
\text { reporting } \\
{[(2+3) \mid 4]} \\
\times 100 \\
\end{array}$ & & \\
\hline $\begin{array}{l}10-14 \text { years } \\
15-19 \text { years } \\
20-24 \text { years } \\
\geqslant 25 \text { years } \\
\text { All ages }\end{array}$ & $\begin{array}{l}0 \\
5 \cdot 73 \\
10 \cdot 02 \\
34.09\end{array}$ & $\begin{array}{l}1.27 \\
1.35 \\
2.30 \\
1.93\end{array}$ & $\begin{array}{l}0.89 \\
2.02 \\
2.37 \\
4 \cdot 02\end{array}$ & $\begin{array}{r}2 \cdot 15 \\
9 \cdot 10 \\
14 \cdot 70 \\
40 \cdot 05\end{array}$ & $\begin{array}{c}(100 \%)^{*} \\
37 \% \\
32 \% \\
15 \%\end{array}$ & $\begin{array}{r}1.77 \\
9.08 \\
21.66 \\
43.69\end{array}$ & $\begin{array}{l}0.14 \\
1.07 \\
2.43 \\
2.70\end{array}$ & $\begin{array}{l}0.54 \\
1.52 \\
2.48 \\
3.13\end{array}$ & $\begin{array}{r}2.45 \\
11.67 \\
26.56 \\
49.52\end{array}$ & $\begin{array}{l}(28 \%)^{*} \\
22 \% \\
18 \% \\
12 \%\end{array}$ & $\begin{array}{l}1 \\
+58 \% \\
+116 \% \\
+\quad 28 \%\end{array}$ & $\begin{array}{l}(+14 \%)^{*} \\
+28 \% \\
+81 \% \\
+24 \%\end{array}$ \\
\hline $\begin{array}{l}\geqslant 10 \text { years } \\
\text { Females }\end{array}$ & 25.78 & 1.86 & $3 \cdot 36$ & 31.00 & $17 \%$ & \multicolumn{2}{|c|}{ Females } & $2 \cdot 68$ & $39 \cdot 46$ & $13 \%$ & $+34 \%$ & $27 \%$ \\
\hline $\begin{array}{l}10-14 \text { years } \\
15-19 \text { years } \\
20-24 \text { years } \\
\geqslant 25 \text { years } \\
\text { All ages }\end{array}$ & $\begin{array}{r}0.07 \\
2.52 \\
3.89 \\
15.29 \\
\\
11.87\end{array}$ & $\begin{array}{l}0.33 \\
0.91 \\
0.85 \\
1.41\end{array}$ & $\begin{array}{l}0.60 \\
0.77 \\
1.20 \\
4.38\end{array}$ & $\begin{array}{r}0.99 \\
4.20 \\
5.94 \\
21.09\end{array}$ & $\begin{array}{c}(93 \%)^{*} \\
40 \% \\
35 \% \\
27 \%\end{array}$ & $\begin{array}{r}0.43 \\
3.09 \\
6.67 \\
21.15\end{array}$ & $\begin{array}{l}0.26 \\
0.60 \\
0.73 \\
2.06\end{array}$ & $\begin{array}{l}0.62 \\
1.07 \\
1.81 \\
3.05\end{array}$ & $\begin{array}{r}1.33 \\
4.76 \\
9.20 \\
27.05\end{array}$ & $\begin{array}{c}(68 \%)^{*} \\
35 \% \\
28 \% \\
19 \%\end{array}$ & $\begin{array}{c}(+514 \%)^{*} \\
+23 \% \\
+71 \% \\
+38 \% \\
+45 \%\end{array}$ & $\begin{array}{c}(+34 \%)^{*} \\
+13 \% \\
+55 \% \\
+28 \% \\
+30 \%\end{array}$ \\
\hline$(\geqslant 10$ years $)$ & 11.87 & $1 \cdot 22$ & 3.47 & $16 \cdot 56$ & $28 \%$ & $17 \cdot 25$ & 1.67 & 2.58 & 21.49 & $20 \%$ & $+45 \%$ & $+30 \%$ \\
\hline
\end{tabular}

a The starting date was 1969 because the category 'undetermined' existed only from the 9th Revision on

$\mathrm{b}$ In the age group 5-9 years, the numbers were very low in all the categories, bringing about large random error

(1) Suicide: E950-E959 (both periods)

(2) Undetermined: E980-E989 (both periods)

(3) Accidental poisoning: 1969-72: E850-E877 (8th Rev.)/1979-84: E850-869 (9th Rev.)

- The numbers were low in all the categories, bringing about unstable rates and percentages

suicide cases $(n=5)$ in $1979-84$ and in $27 / 40$ cases in 1979-84. For girls, there was only one case of drowning around $1970(n=1)$. In the period around 1981 , the cases $(n=9)$ were equally divided between poisoning, hanging, drowning and jumping.

For the period 1979-84, a more detailed analysis of the method was possible through the fourth digit of the ICD-9 code. The use of medicaments was reported in $84 \%$ of all suicidal self-poisoning deaths (E950; $n=210)$, most frequently barbiturates $(17 \%)$, but the type of medicament was not mentioned in $42 \%$. In $8 \%$ of all firearm-cases (E955; $\mathrm{n}=223)$ a sporting gun was used, and in $1 \%$ a handgun, but the type of weapon was not specified in $89 \%$ of cases.

To estimate the amount of under-reporting of suicide deaths, which probably brings about larger bias in young age groups than in adults, ${ }^{148}$ the trends in the undetermined and accidental poisoning categories - the most likely categories of misclassification ${ }^{16} 18$-were investigated, and an "estimated suicide" rate was calculated as described. ${ }^{16}$ Table 3 shows the results. The under-reporting seemed to decrease with increasing age in both sexes, to be larger around 1970 than around 1981-not exceeding $40 \%$ above 15 years of age however-and to be larger in females than in males-maybe reflecting the more frequent use of silent methods.

The table also shows that a decreased level of under-reporting between 1970 and 1981 could only explain a small part of the suicide increase above the age of 14 years. Moreover, the estimate presented is almost certainly an overestimation because not 
Table 4 Weighted ${ }^{I}$ Pearson product moment correlation coefficients between the suicide rate (ages 15-24 years) and selected explanatory variables around 1970 and 1981; Belgian arrondissements $(n=43)$

\begin{tabular}{|c|c|c|c|c|}
\hline \multirow[b]{2}{*}{ Variables } & \multicolumn{2}{|c|}{ Around 1970} & \multicolumn{2}{|c|}{ Around 1981} \\
\hline & Males & Females & Males & Females \\
\hline \multicolumn{5}{|l|}{ (a) Sex-independent: } \\
\hline $\begin{array}{l}\text { Natural population change } \\
\text { Households } \geqslant 5 \text { persons } \\
\text { Foreigners } \\
\text { Immigration } \\
\text { Emigration } \\
\text { Illegitimacy } \\
\text { Low tax income } \\
\text { Population density } \\
\text { Persons per room } \\
\text { Houses built before } 1919 \\
\text { Households/T.V. set } \\
\text { Households/car } \\
\text { Houses without telephone } \\
\text { Houses without running water }\end{array}$ & $\begin{array}{l}-0.59 \ddagger \\
-0.54 \ddagger \\
+0.42 t \\
+0.32 * \\
+0.46 t \\
+0.56 \ddagger \\
-0.51 \ddagger \\
+0.41 t \\
-0.59 \ddagger \\
+0.45 t \\
-0.14 \\
+0.17 \\
-0.53 \ddagger \\
-0.41 \dagger\end{array}$ & $\begin{array}{l}-0.48 \dagger \\
-0.42 \dagger \\
+0.28 * \\
+0.50 \ddagger \\
+0.56 \ddagger \\
+0.54 \ddagger \\
-0.57 \ddagger \\
+0.54 \ddagger \\
-0.40 \dagger \\
+0.23 \\
+0.18 \\
-0.01 \\
-0.64 \ddagger \\
-0.39 t\end{array}$ & $\begin{array}{l}-0.24 \\
-0.26^{*} \\
+0.45 t \\
+0.28^{*} \\
+0.38 \dagger \\
+0.48 \dagger \\
+0.09 \\
+0.43 \dagger \\
-0.38 \dagger \\
+0.23 \\
+0.38 \dagger \\
+0.22 \\
-0.10 \\
+0.43 \dagger\end{array}$ & $\begin{array}{l}-0.36 t \\
-0.44 \dagger \\
+0.56 \pm \\
+0.15 \\
+0.28^{*} \\
+0.68 \ddagger \\
+0.07 \\
+0.43 \dagger \\
-0.61 \ddagger \\
+0.37 \dagger \\
+0.54 \ddagger \\
+0.29 * \\
-0.18 \\
+0.30^{*}\end{array}$ \\
\hline \multicolumn{5}{|l|}{ (b) Sex-specific: } \\
\hline $\begin{array}{l}\text { < } 15 \text { years old } \\
\text { Divorced } \\
\text { Widowed } \\
\text { Living alone } \\
\text { Unskilled } \\
\text { Lower education } \\
\text { Working in agriculture } \\
\text { Professional population } \\
\text { Unemployed } \\
\text { Births to women }<20 \text { years old } \\
\text { Births to women } \geqslant 30 \text { years old }\end{array}$ & $\begin{array}{l}-0.55 \pm \\
+0.60 \pm \\
-0.07 \\
+0.51 \ddagger \\
-0.20 \\
-0.52 \ddagger \\
-0.22 \\
-0.11 \\
-0.09 \\
1\end{array}$ & $\begin{array}{l}-0.48 \dagger \\
+0.59 \ddagger \\
+0.31^{*} \\
+0.49 \ddagger \\
+0.30^{*} \\
-0.56 \ddagger \\
+0.02 \\
+0.41 \dagger \\
-0.04 \\
-0.01 \\
+0.27^{*}\end{array}$ & $\begin{array}{l}-0.04 \\
+0.43 \dagger \\
-0.20 \\
+0.45 \dagger \\
-0.09 \\
-0.15 \\
-0.08 \\
-0.38 \dagger \\
+0.21 \\
1 \\
1\end{array}$ & $\begin{array}{l}-0.36 t \\
+0.60 \pm \\
+0.45 t \\
+0.67 \pm \\
+0.23 \\
-0.10 \\
+0.21 \\
-0.10 \\
-0.32^{*} \\
+0.41 \dagger \\
+0.32^{*}\end{array}$ \\
\hline
\end{tabular}

$\mathrm{p}<0.05 ; \mathrm{t}<0.01 ; \pm \mathrm{p}<0.001$

1 Weighted with the reciprocal of the variance of the mortality rate

all the accidental and undetermined deaths are suicides.

Next, the geographical pattern was investigated. This analysis will be reported in detail elsewhere. The numbers were generally very low, bringing about large random variation in the rates and making interpretation difficult. Arrondissements which contain large cities (such as Brussels, Antwerp, Liège, Kortrijk, Charleroi, Brugge and Hasselt) tended to have the highest rates and the largest increases, especially in males.

Finally, a weighted ecological correlation analysis was performed, associating the variation in youth suicide with the variation in a selection of 25 variables measuring social integration and socio-economic level (table 4). The variables most strongly associated with high youth suicide levels in both periods were (1) the proportion of illegitimate births, (2) the proportion of divorced persons, and (3) the proportion of persons living alone. These three variables were also strongly intercorrelated $(r+0.8$ approx.). The number of persons per room was correlated with the family size and the natural population growth. Socio-economic variables overall showed weaker and less consistent associations.

\section{Discussion}

Our study of trends in youth suicide in 21 European countries indicated first, that there was a tendency to increased rates among 5-14 year-old boys although the precision of the rates was very low; and second, that in male adolescents and young adults (15-24 years old) the rates have risen obviously. In females the increases were less pronounced and there were even decreases of more than $10 \%$ in Sweden, Czechoslovakia, Finland, England \& Wales, and West Germany. No important shifts occurred in the rank order of the countries and the relative contribution in the overall burden of suicide hardly changed.

In Belgium, youth suicide increased after 1970 in the age group 15-24 years, and this was most prominent in the 20-24 year-olds, especially males. Girls of 15-19 years showed only small increases. In children under 15 , the male rates tended to increase after 1975 . Around 1981, about half of all youth suicides in the 15-24 year age range were committed by methods which could be influenced by reducing their availability: medicaments (barbiturates in $17 \%$ of the cases) and firearms (sporting guns in $8 \%$ ). Between 1970 and 1981 , the rate for these two methods showed 
two- to threefold increases in both sexes, a higher figure than in the adult ages. Increase in the use of medicaments was more pronounced among females, firearms among males. In boys younger than 15, hanging seemed the most preferred method, although the numbers were too small to allow any sound conclusion. The estimated under-reporting error diminished with increasing age and over the past ten years. It was also larger in females. However, the trends did not change greatly when the influence of under-reporting was taken into account. Finally, youth suicide was found strongly associated with indicators of anomie and social disintegration in both sexes, and less with socio-economical variables. Arrondissements containing large cities tended to have the highest rates.

Some findings were consistently apparent when comparing our results with other studies. ${ }^{2-9} 18$ Suicide increased obviously in young males of 15 years and older but the rise was most prominent in the 20-24 year-olds. The use of firearms became much more frequent: the most dramatic increase has been reported from the United States ${ }^{5-9}$ (also among the 15-19 year-olds), where firearms accounted for more than $60 \%$ of all youth suicides around $1980 .^{7}$ Although the male rate for all methods combined was only slightly higher than the Belgian figure, the firearm rate was still about three times higher. Age-, sex- and method-specific patterns, comparable to the Belgian trends, were reported from France $^{3}$ (although proportional figures were used). In England and Wales, ${ }^{418}$ the increase in males was much less pronounced and the rates were still half the Belgian level. Increasing uses of exhaust gas and of solid and liquid substances were reported but important trends in firearms rates were not stressed. ${ }^{4}{ }^{18}$ Undetermined and accidental poisoning rates were decreasing, ${ }^{18}$ although in the age group 10-14 years an increase was found until 1980 , especially in girls. ${ }^{4}$ Although the Dutch rates remained about half the Belgian figures, a sudden increase from the early 1970 s on was also reported from the Netherlands. ${ }^{19}$

A particular finding, requiring further investigation, was the decrease in female youth suicide in a number of European countries. We are not aware of any studies relating youth suicide to sociodemographic variables on an aggregated level.

There is much room for speculation about the determinants of these trends. It is not clear why males became more vulnerable than females and why especially above the age of 20 . As we have shown, a differential under-reporting could not explain away this finding. The use of less lethal methods 1 could be a partial explanation but a confirmation requires the study of attempted suicides (parasuicide) in relation to completed suicides. ${ }^{20} \mathrm{~A}$ differential psychological or physiological development, ${ }^{21}$ apart from or associated with differences in social supporting systems, has also to be investigated. These could explain differing abilities to cope with the increasing stress of a more precocious independent life. The strong association of youth suicide with variables reflecting social isolation has also been found at the individual level..$^{13721}$ The associations of adolescent suicide with perinatal and maternal conditions, ${ }^{22}$ with child abuse and neglect, ${ }^{23}$ and with alcohol-abuse ${ }^{6}$ could indeed reflect a clustering of anomic conditions.

The question whether youngsters use more violent or lethal methods ${ }^{21} 24$ than adults cannot be clearly answered. In boys, hanging and, in adolescence, firearms were apparently in favour but the frequent use of medicaments in adolescents was against such an hypothesis. At any rate, a valid answer to this question can only be obtained through the study of all (fatal and non-fatal) suicide attempts ${ }^{20}$ on a representative population base.

Our results could point to some practical consequences for individual and population-based prevention. Although there is no unequivocal evidence about the effect, many investigators are convinced that the availability of lethal methods in impulsive suicides is an important and neglected factor. ${ }^{7-9} 2025$ The frequency of impulsive suicides or attempts is known to be higher among the young. ${ }^{17}$ Doctors or counsellors confronted with depressed young persons, in particular those with a history of suicidal behaviour, should always inquire about potential access to lethal methods such as firearms or toxic drugs and should try to remove these. ${ }^{9}$

On the population level, regulations and recommendations about the access to firearms and medications for young people need to be discussed and implemented. ${ }^{5-1021}$ In Belgium, this proposition is further corroborated by the increase in use of these methods among adults as well. However, public awareness must be increased with caution, for an adverse effect of making the problem public has been documented. ${ }^{2627}$ At the primary preventive level, more attention should be paid to the social and emotional support systems of young people. ${ }^{21}$

Finally, methodological limitations in our analysis have to be considered. First, large random variation was present, especially in children. Second, differential validity and reliability of the data could affect the comparisons. The definition and diagnosis of suicide in children, ${ }^{24}$ the pressure upon the reporting physician, and the ascertainment procedure could vary importantly and the variation could be larger in the young. ${ }^{824} \mathrm{~A}$ larger under-reporting than among adults was suggested by our results. However, above the age of 15 , the under-reporting error was not found to bias the trends. Moreover, the figures presented 
almost certainly overestimate the effect, for only a part of the accidental and undetermined deaths are in reality suicides. Proportions of $9 \%$ and $45 \%$ respectively have been reported ${ }^{6}$. Third, it has to be remembered that the correlation coefficients presented cannot be considered as determinants or as risk estimates. ${ }^{14}$

We would like to thank M Verlinden at the Ministry of Public Health (Brussels), E Rosselle and M Donneux at the National Institute of Statistics (Brussels) for the provision of the raw data. We are grateful to J Boon, AM Pot and M Leijnen for the editorial assistance. This research was performed while Dr G Moens was a scholar of the Belgian National Fund for Scientific Research (Brussels).

\section{References}

${ }^{1}$ Hawton K. Suicide and attempted suicide among children and adolescents. London: Sage Publ, 1987.

2 Report on a WHO Working Group. Changing patterns in suicide behaviour. Euro Reports and Studies 74. Copenhagen: Regional Office for Europe WHO, 1982.

${ }^{3}$ Choquet M, Facy F, Davidson F. Suicide and attempted suicide among adolescents in France. In: Farmer $R$, Hirsch S eds. The suicide syndrome. London: Croom Helm, 1980.

4 McClure GMG. Trends in suicide amongst the young. $\mathrm{Br} J$ Psychiatr 1984; 144: 134-8.

5 Simmons K (editorial). Adolescent suicide: second leading death cause. JAMA 1987; 257: 3329-30.

6 Brent DA, Perper JA, Allman CJ. Alcohol, firearms and suicide among youth. JAMA 1987; 257: 3369-72.

${ }^{7}$ Rosenberg ML, Smith JC, Davidson LE, Conn JM. The emergence of youth suicide: an epidemiologic analysis and public health perspective. Ann Rev Public Health 1987; 8: 417-40.

${ }^{8}$ Holinger PC. Adolescent suicide: an epidemiological study of recent trends. Am J Psychiatr 1978; 135: 754-6.

${ }^{9}$ Boyd JH, Moscicki EK. Firearms and youth suicide. Am J Public Health 1986; 76: 1240-2.
${ }^{10}$ Simmons K (editorial). Task force to make recommendations for adolescents in terms of suicide risk. JAMA 1987; 257: 3330-2.

11 World Health Organisation. World health statistics annual 1986. Geneva: WHO, 1986.

12 Moens GFG, van Oortmarssen GJ, Honggokoesoemo S, van de Voorde $H$. Birth cohort analysis of suicide mortality in Belgium 1954-1980 by a graphic and a quantitative method. Acta Psychiatr Scand 1987; 76: 450-5.

13 Moens GFG. The rise of suicide mortality in Belgium between 1968-72 and 1979-81: age, sex and geographical characteristics. Int J Epidemiol 1984; 13: 243-5.

14 Nie NH, Hull CH, Jenkins JG, Steinbrenner K, Bent DH. Statistical package for the social sciences. New York: McGraw-Hill Co, 1981.

${ }^{15}$ Ministry of Public Health. Statistical Yearbook 1983. Brussels: Ministry of Public Health, 1985.

16 Adelstein A, Mardon C. Suicides 1961-74. Population Trends 1975; 2: 13-6.

17 Armitage P. Statistical methods in medical research. London: Blackwell, 1971.

18 McClure GMG. Suicide in England and Wales 1975-84. Br J Psychiatr 1987; 150: 309-14.

${ }^{19}$ Kienhorst CMW, Broese van Groenon MI. Jongeren en zelfdoding. In: Wolters WHG, Diekstra RFW, Kienhorst CWM, eds. Suicidaal gedrag bij kinderen en adolescenten. Baarn: Ambo, 1987.

${ }^{20}$ Farmer RDT. The relationship between suicide and parasuicide. In: Farmer $\mathrm{R}$, Hirsch $\mathrm{S}$, eds. The suicide syndrome. London: Croom Helm, 1980.

${ }^{21}$ Black D. Adolescent suicide: preventive considerations. $\mathrm{Br}$ Med J 1986; 292: 1620-71.

22 Salk L, Lipsitt LP, Sturner WQ, Reilly BM, Levat RH. Relationship of maternal and perinatal conditions to eventual adolescent suicide. Lancet 1985; i: 624-7.

${ }^{23}$ Deykin EY, Alpert JJ, McNamara JJ. A pilot study on the effect of exposure to child abuse or neglect on adolescent suicidal behaviour. Am J Psychiatr 1985; 142: 1299-303.

${ }^{24}$ Kosky R. Suicide and attempted suicide among Australian children. Med J Austr 1982; 1: 124-6.

${ }^{25}$ Farmer R, Rohde J. Effect of availability and acceptability of lethal instruments on suicide mortality: an analysis of some international data. Acta Psychiatr Scand 1980; 62: 436-46.

26 Phillips DP, Carstensen LL. Clustering of teenage suicides after television news stories about suicide. $N$ Engl J Med 1986; 315: 685-9.

${ }^{27}$ Gould MS, Shaffer D. The impact of suicide in television movies. N Engl J Med 1986; 315: 690-707. 